\title{
Justification of the line of action for reclamation of lands disturbed by opencast mining
}

\author{
Y.D.Smirnov ${ }^{1}$, D.V. Suchkov ${ }^{1}$, and T.V. Goryunova ${ }^{2}$ \\ ${ }^{1}$ The Department of Genecology, Saint Petersburg Mining University, Saint Petersburg, Russia \\ ${ }^{2}$ General Director, Company Limited GPCompany, Saint Petersburg, Russia
}

\begin{abstract}
The article is devoted to the substantiation of the line of action for reclamationof disturbed lands. The object of reclamation is a land plot (Russia, Leningrad Region), disturbed as a result of unauthorized open-pit mining operations for the extraction of limestone. In order to obtain the information necessary to justify the reclamation project, the following works were carried out: reconnaissance and route observations, topographic, geological, and environmental surveys of the land. Based on the results of the generalized study data of the environmental and economic justification, a line of action for agricultural reclamation was chosen. In addition, an assessment of the estimated cost of the event was carried out and a list of necessary works was proposed within the framework of the technical and biological stages of reclamation.
\end{abstract}

\section{Introduction}

The results of economic activities of the past years may reflect not only the growth of industrial production but also the level of responsibility for negative consequences. Thus, the problem of land degradation (deterioration of their quality) as a result of anthropogenic impact is one of the most urgent both in Russia and in the world. The main danger of land degradation processes is associated with the impossibility of their further use and their withdrawal from economic circulation, in other words, the formation of disturbed lands. To eliminate such negative consequences of economic activity, it is necessary to carry out a set of works aimed at restoring land, as well as improving the state of the land resources. Such measures to prevent land degradation and (or) restore their fertility are called reclamation of disturbed lands. The purpose of reclamation is to bring disturbed lands into a condition suitable for their use in accordance with their intended purpose, including by eliminating the consequences of soil pollution, restoring the fertile soil layer, and creating protective forest plantations.

A huge amount of land resources is depleted during the extraction of minerals. In particular, opencast mining (OCM) is one of the main causes of disturbed land formation. For example, the first reclamation activities in the USSR were associated with processes such as the extraction of shale, brown coal, and iron ores by OCM. Unfortunately, at 
present, the rate of land reclamation is significantly lagging behind the rate of disturbance by OCM, which is one of the most pressing environmental problems in the mining industry. This is relevant not only for large fields, but also for smaller-scale cases of local subsoil areas development (including unauthorized ones) [1]. According to the Law of the Russian Federation "On Subsoil" N 2395-1 dated 21.02.1992 (as amended on 30.05.2020), deposits of common minerals (sand, gravel, clay, limestone, etc.) belong to local subsoil areas.

The aim of this study is to justify the line of action for reclamation of land plots disturbed as a result of unauthorized OCM operations for the extraction of limestone. A land plot for reclamation with an area of 5.4 ha is located in the Leningrad region on lands of agricultural designation. During the reconnaissance survey of the territory, five quarries with a depth of up to $10.0 \mathrm{~m}$, which were developed without any permits for at least one year,were identified. At the time of the survey of the territory, mining operations were not carried out in the quarries. The estimated volume of limestone excavation based on the results of geodetic surveys amounted to 18 thousand $\mathrm{m}^{3}$.

Presently, the owner of the land plot is the administration of the municipality in the Leningrad Region. However, according to the Decree of the Government of the Russian Federation №140 dated 23.02.1994, the reclamation of lands disturbed by a legal entity during all work related to the violation of the surface of the soil is carried out at the expense of the legal entities' own funds. Thus, the responsibility for compensation for the damage caused to the land lies with the organization that previously operated it. This determines the relevance of the need for reclamation of disturbed lands.

The final stage of this study will be the issuance of appropriate recommendations on the procedure for carrying out the necessary works within the technical and biological stages of reclamation, taking into account the chosen line of action for the reclamation, as well as on the basis of an assessment of the environmental and economic feasibility of the event.

The stages of the research are:

- Obtaining information sufficient for characterization of the researched area

- Inventory of disturbed lands

- Determination of the degree of land degradation of the site

- Determination of soil fertility and the possibility of use, when working to restore disturbed areas

- Assessment of soil contamination to determine the possibility of its use in reclamation

- Identification of centers of waste accumulation on the territory of the land plot

- Determination of the geological features of the underlying soils

- Collection and preparation of data for the development of a reclamation project.

To obtain the data necessary for the preparation of design documentation for reclamation, i.e., about the state of environmental components, the nature of disturbances in the territory, and the degree of its degradation, identification of possible sources of pollution, the following works were performed:

1 Engineering and geodetic surveys, including a detailed survey of the territory to identify disturbed lands and study the parameters of disturbance

2 Geological survey: determination of the geological structure, allocation of engineering and geological elements with different physical and mechanical properties, the study of these properties

3 Environmental survey: selection and research of soils for chemical, parasitological, as well as bacteriological pollution, and the study of fertility or potential fertility of soils at the land plot, in order to clarify the degree of their degradation [2]

4 Route survey of the territory to determine the boundaries of disturbed areas, clarification of the disturbances scale, and the development of a preliminary scheme of reclamation. 


\section{Materials and methods}

The object of reclamation is the 5.4 ha land plot located in the Leningrad Region. The land is owned by the administration of the municipality. The land is free from buildings; there are no engineering networks, water bodies and underground exits to the surface within it. The landscape of the land is anthropogenically disturbed. It was revealed that the land has no restrictions on use, since:

- Widespread minerals listed on the state balance sheet are absent

- Burial places of animal corpses and established sanitary protection zones of such objects are absent

- There are no specially protected natural areas within the boundaries of the land and do not adjoin it

- The territory of the projected object does not infringe the boundaries of water protection zones of water bodies and zones of sanitary protection of drinking water supply sources.

The conducted route surveys of the territory detected no objects of flora and fauna included in the Red Data Book of the Leningrad Region and the Russian Federation.

Geological works were carried out in order to determine the actual state of soils on the reclamation territory. As part of the geological study, the following works were carried out:

1 Reconnaissance route survey

The main goal was to determine the boundaries of disturbed areas and highlight the main lithological varieties. The route survey was carried out in dry, clear weather. During the survey, the scale of the disturbance was clarified and a preliminary scheme of the reclamation work was developed.

2 Exploratory drilling of wells in order to clarify the geological structure of the land

Wells with a diameter of $64 \mathrm{~mm}$ were drilled using a screw tool. The main purpose of drilling was to determine the thickness of loose rocks and take samples. Locations of the wells are shown in Figure 1.

3 Investigation of samples obtained as a result of drilling

As a result of the sample studies, the granulometric composition of the soil was determined and the stability parameters of the walls of quarries were evaluated to determine the possibility of using this soil for backfilling the worked-out areas. Particle size analysis was performed to confirm the determination of the loose material. Geomechanical studies of the soil were carried out to determine the stability of the slopes in the case of their planning with the available soils.

To create a planned-high-altitude base on the territory for performing a topographic survey of scale M 1:2000, 4 points were laid (GPS1, GPS2, GPS3, GPS4). The coordinates and heights of the base points were determined using the LEICA GS-08, LEICA GS-10 satellite geodetic equipment from the points of the state geodetic network. For the production of topographic survey and drawing up a topographic plan, a shooting base was created from the above points. A theodolite passage was laid for the shooting base. The topographic survey was performed with a Sokkia 650RX electronic total station. The CREDO program equalized the plan-high-rise justification parametrically. Processing of the materials from the field engineering and geodetic surveys was carried out using Credo DAT 4.0, AutoCAD programs. The initial data included working files exported from GNSS receivers and electronic total stations [3]. The results of the topographic survey are presented in the form of a topographic plan of scale M 1:2000 with a relief section of $0.5 \mathrm{~m}$.

The environmental survey of the land included:

1 Morphological description of the soil section 
During the field work, as part of the environmental survey, a morphological description of the 1 st soil section was carried out to classify the types of soils within the surveyed area. The soil section was established in the most typical plant community of its area.

2 Assessment of agrochemical soil properties

When carrying out earthworks related to land reclamation, it is necessary to establish requirements for the protection of the fertile soil layer (its removal and rational use) [4]. Fertile and potentially fertile topsoilsto be used for biological land reclamation must meet the requirements [5]. To assess the agrochemical properties of soils within the studied land plot, soil samples were taken from the fertile and potentially fertile topsoils to further determine their suitability for reclamation.

3 Assessment of the sanitary-chemical and biological state of soils

The assessment was carried out in accordance with the requirements of the Code of Practice "SP 47.13330.2016 Engineering survey for construction. Basic principles". Sampling was carried out in the surface soil layer $(0.0-0.2 \mathrm{~m})$ for the analysis of chemical, microbiological and parasitological parameters. The general assessment of the sanitary state of the soil was carried out according to the requirements [17]. The hygienic assessment of soil contamination was carried out by comparing the maximum permissible concentrations (MPCs) or approximately permissible concentrations (APCs) of chemical substances with their actual content. The values of MPCs and APCs of soil pollutants were adopted in accordance with the hygienic standards of the Russian environmental legislation [5].

To determine the content of pollutants, the following methods were used:

- $\mathrm{pH}$ : potentiometric determination of the $\mathrm{pH}$ of the salt extract of the soil

- Heavy metals ( $\mathrm{Pb}, \mathrm{As}, \mathrm{Cd}, \mathrm{Zn}, \mathrm{Ni}, \mathrm{Cu})$ : method of atomic absorption spectroscopy

- Hg: method of atomic absorption spectroscopy using a hydride attachment (mercury analyzer)

- 3,4- benzo (a) pyrene: high performance liquid chromatography method

- oil products: fluorometric analysis method.

\section{Results}

The reconnaissance route survey and the description of the observation sites revealed that about $30 \%$ (1.4 ha) of the study area was disturbed by OCM during the unauthorized limestone mining. With the exception of the quarries, the entire surface of the land plot is covered with vegetation. The bedrock is limestone overlain by a relatively thin (up to 0.5 m) layer of calcareous loam. A soil-vegetation layer up to $20 \mathrm{~cm}$ thick is located on the loam. The study of the walls of the quarries showed a high degree of fracturing of the nearsurface zone of limestones.

As a result of topographic work, it was revealed that the land plot is a group of disturbed territories (quarries) up to $10.0 \mathrm{~m}$ deep, which represent mechanical destruction of the soil cover. A situational plan indicating the locations of the quarries and their number is shown in Fig. 1. Parameters of the quarries are presented in Table 1. 


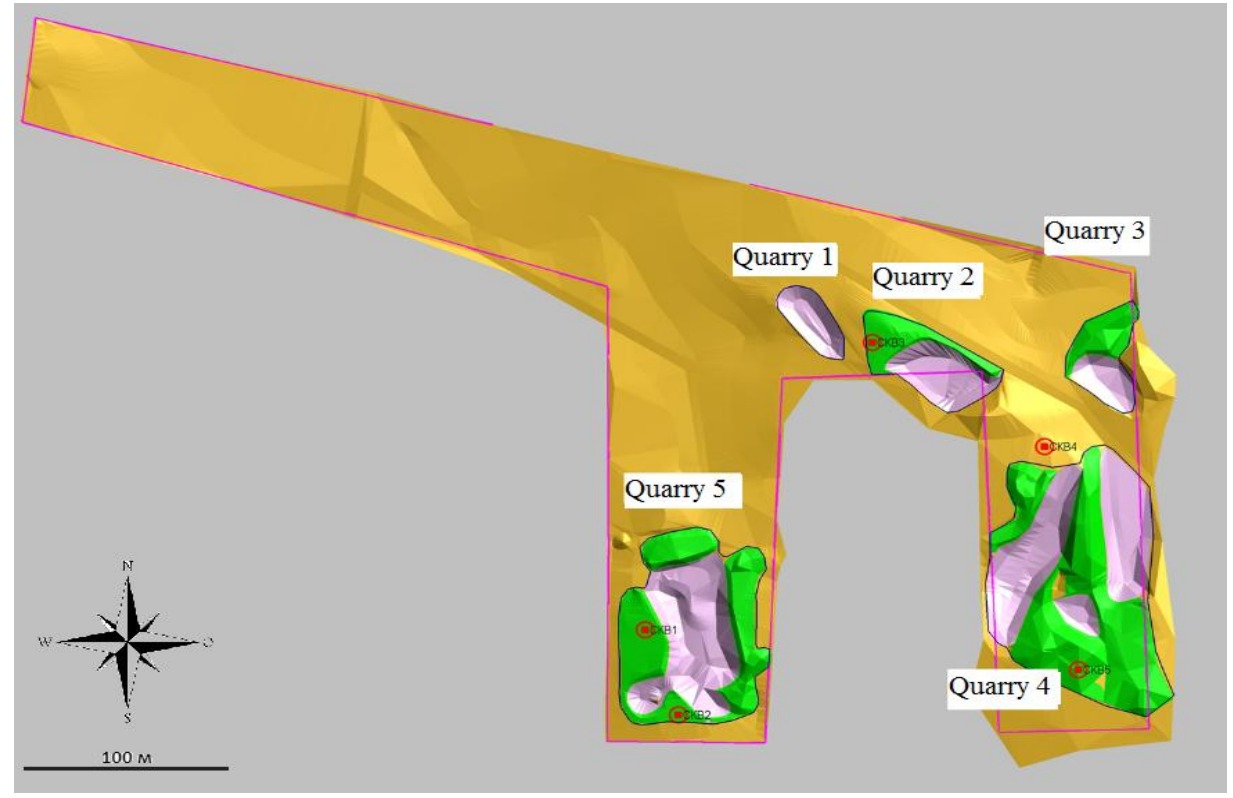

Fig. 1. Situational plan of the land plot.

Table 1. Parameters of the quarries within the boundaries of the land plot.

\begin{tabular}{|c|c|c|c|c|}
\hline \multirow[t]{2}{*}{$\begin{array}{c}\text { № } \\
\text { quarry }\end{array}$} & Totalarea & $\begin{array}{c}\text { Area within the } \\
\text { boundaries of the } \\
\text { land plot }\end{array}$ & Proportions(length*width) & Maximumdepth \\
\hline & \multicolumn{2}{|c|}{ thousand $\mathrm{m}^{2}$} & $\mathrm{~m} * \mathrm{~m}$ & $\mathrm{~m}$ \\
\hline 1 & 0.7 & 0.7 & $45 * 18$ & 3.0 \\
\hline 2 & 1.2 & 0.5 & $47 * 27$ & 6.0 \\
\hline 3 & 1.3 & 0.8 & $45 * 32$ & 3.0 \\
\hline 4 & 7.6 & 7.4 & $142 * 70$ & 8.0 \\
\hline 5 & 4.6 & 4.6 & $120 * 38$ & 7.0 \\
\hline
\end{tabular}

During the survey of the land plot in the mined-out area of the quarry No. 4, used car tires and wood wastes were detected. In the mined-out area of the quarry No. 3, a disposal of municipal solid wastes was detected.

The main material of the dumps has a transitional composition from sandy loam to loam (the content of clay particles is 6-16\%). The angle of internal friction (angle of repose) is $16-22^{\circ}$, which with a large margin ensures the stability of the projected slopes. Based on the results of route work, drilling and study of the quarries walls, the following geological and lithological section was drawn up (Table 2).

Table 2. Geological and lithological section.

\begin{tabular}{cccl}
$\begin{array}{c}\text { № } \\
\text { layer }\end{array}$ & Layername & $\begin{array}{c}\text { Thickness, } \\
\mathrm{m}\end{array}$ & \multicolumn{1}{c}{ Description } \\
\hline 1 & Topsoil & $0-0,2$ & $\begin{array}{l}\text { Gray-yellow calcareous sandy loam with an admixture } \\
\text { of humus (up to } 30 \% \text { ) and fine grains of limestone } \\
\text { gravel (less than } 5 \% \text { ). }\end{array}$ \\
A layer of gray-yellow calcareous sandy loam \\
underlying the topsoil. A sharp decrease in the number \\
of organic particles is observed. In the bottom zone, an \\
increase in the proportion of limestone gravel is \\
observed. \\
Layer of transition of sandy loam into eluvium of \\
bedrock. The share of gravel and crushed limestone is
\end{tabular}



$4 \quad$ Eluviumofbedrock
$2-7$
more than $50 \%$
Strongly disintegrated yellowish-white limestone. The

$5 \quad$ Bedrock $\quad-$ average particle size is from $5-10 \mathrm{~cm}$ at the roof to 20 - $30 \mathrm{~cm}$ at the bottom. Fracturing disappears with depth. Monolithic yellowish-white strongly fractured limestone. The layer is exposed at the bottom of the quarries.

The main purpose of the OCM was the extraction of layer 4 , i.e., natural crushed limestone [6]. The studies have shown the identity of the sandy loam in undisturbed zones with the sandy loam from the dumps. Therefore, this soil can be used for reclamation to backfill the mined-out space [7].

In the course of the morphological description, it was established that soddy-podzolic typical light loamy soil became widespread within the boundaries of the site. A very low degree of soil humus is commonwithin the scope of the land plot. According to the results of laboratory analysis, in the fertile and potentially fertile topsoil, the mass fraction of humus is $<2 \%$. It does not meet the requirements (hereinafter - the requirements in accordance with [5]). The $\mathrm{pH}$ value of the aqueous extract in the fertile topsoil should be 5.5-8.2 pH. In all selected soil samples, the $\mathrm{pH}$ value does not exceed the specified range. In the fertile topsoil, the mass fraction of soil particles $<0.1 \mathrm{~mm}$ should be in the range of $10-75 \%$. In the selected soil samples, the actual mass fraction of particles $<0.1 \mathrm{~mm}$ in the fertile layer was $17.3 \%$, in the potentially fertile layer it amounted to $22.2 \%$. Thus, the fertile soil layers meet the established requirements. On the soils that are heavily, gravelly, strongly, and very strongly stony, the rate of the removal of fertile and potentially fertile topsoil has not been established. According to the results of the granulometric composition analysis in the selected soil samples, fractions $>10 \mathrm{~mm}$ in size are absent, which meets the requirements.

Thus, this soil cannot be used as a fertile topsoil for further reclamation.

The results of the obtained concentrations of gross forms of heavy metals, oil products, and benzo(a)pyrene in a selected soil sample are presented in Table 3.

Table 3. Concentrations of pollutants in the soil sample of the surveyed area.

\begin{tabular}{|c|c|c|c|c|c|c|c|c|c|c|c|}
\hline \multirow{2}{*}{$\begin{array}{l}\text { Sampling } \\
\text { depth, } \mathrm{m}\end{array}$} & \multirow{2}{*}{$\begin{array}{c}\text { Soilty } \\
\text { pe }\end{array}$} & \multirow[b]{2}{*}{$\mathrm{pH}$} & \multicolumn{9}{|c|}{ Gross content of determined components, $\mathrm{mg} / \mathrm{kg}$} \\
\hline & & & $\begin{array}{c}3,4- \\
\text { benzo(a)pyrene }\end{array}$ & $\begin{array}{l}\text { Oilprodu } \\
\text { cts }\end{array}$ & $\mathrm{Hg}$ & $\mathrm{Pb}$ & As & $\mathrm{Cd}$ & $\mathrm{Zn}$ & $\mathrm{Ni}$ & $\mathrm{Cu}$ \\
\hline $0.0-0.2$ & $\begin{array}{l}\text { Sandy } \\
\text { loam }\end{array}$ & 7 & 0.0155 & 38 & $\begin{array}{c}<0 \\
.0 \\
05\end{array}$ & 7 & $\begin{array}{l}<0 . \\
05\end{array}$ & $\begin{array}{c}<0.0 \\
5\end{array}$ & $\begin{array}{l}2 \\
3\end{array}$ & $\begin{array}{l}1 \\
0\end{array}$ & $\begin{array}{l}1 \\
6\end{array}$ \\
\hline \multicolumn{3}{|c|}{ MPC (APC) } & 0.02 & 1000 & $\begin{array}{c}2 . \\
10\end{array}$ & 32 & 2.0 & 0.50 & $\begin{array}{l}5 \\
5\end{array}$ & $\begin{array}{l}2 \\
0\end{array}$ & $\begin{array}{l}3 \\
3\end{array}$ \\
\hline
\end{tabular}

As can be seen from Table 3, in the selected soil sample, the content of heavy metals and metalloids of gross forms does not exceed the established MPC and APC. The content of oil products does not exceed the permissible level of soil contamination provided for by the Methodological Recommendations for the identification of degraded and contaminated lands (approved by the Ministry of Natural Resources of the Russian Federation on February 15, 1995). In accordance with [17], the sampled soil belongs to the "Clean" category of pollution in terms of the content of metals, metalloids and benzo(a)pyrene. In terms of the total pollution indicator $(\mathrm{Zc})$, the studied soil belongs to the "Permissible" category of pollution. According to the degree of epidemiological danger, the sampled soil in all samples belongs to the "Clean" category. Therefore, according to chemical, biological, parasitological indicators, the soil belongs to the category "Clean" and can be used for reclamation without restrictions [8]. 


\section{Discussion}

Based on the information on the land plot category, data obtained during the inventory of disturbed areas and the study of their actual state, as well as taking into account the opinion of the owner of the land, the agricultural line of action was chosen for reclamation [9]. The agricultural line implies, among other things, the creation of a fertile topsoil on disturbed lands, characterized by the content of organic matter and other physicochemical and agrochemical indicators necessary for agriculture.

The following characteristics are taken into account as the main criteria when choosing the line of action for reclamation, as well as when justifying planned activities and technological solutions [10]:

1 The category and permitted use of the land plot

Taking into account that the category of the land plot is agricultural, the priority line of action for restoration is the creation of an agricultural land area.

2 Opinion of the owner of the land to be reclaimed

The requirements for reclamation put forward by the Administration of the municipality are suitable for the agricultural line of reclamation.

3 Actual and predicted state of disturbed lands by the time of reclamation

Based on the small area and depth of the quarries (Table 1) and the angle of the excavation slope, it is possible to ensure flattening of the sides of disturbed areas at an angle of up to $5^{\circ}$, taking into account the terrain, which corresponds to the recommendations for the relief for agricultural lands. When backfilling quarries, a single landscape is formed without sharp altitude changes to exclude the occurrence of wetlands, which is also favorable for agricultural lands.

The soil of the investigated area by chemical, biological, and parasitological indicators belongs to the category "Clean" and can be used for reclamation without restrictions.

Agrochemical studies of the soil showed that within the boundaries of the land plot, the fertile and potentially fertile topsoil does not correspond the requirements (very low degree of soil humus: the mass fraction of humus is $<2 \%$ ). Therefore, within the boundaries of the land plot, the norms for removing the fertile and potentially fertile topsoil for the purpose of its rational use are not satisfactory. This soil cannot be used as fertile topsoil for further reclamation.

Considering the small number of quarries, small areas of disturbed land plots, the presence of the soils suitable for backfilling the quarries, and the need to apply the fertile topsoil with a thickness of up to $0.3 \mathrm{~m}$, it will be economically and environmentally expedient to organize the delivery of the missing part of the soil for the subsequent return of the land plot to a state suitable for agricultural needs [11].

4 Natural and climatic characteristics

Natural and climatic characteristics are the most suitable for the agricultural line of action for reclamation. On the territory of the land plot, no aquifer has been opened. Heavily fractured limestone is a highly permeable material that has no capillary effect; therefore water enters the territory only in the form of atmospheric precipitation. Lime sandy loam has a low filtration coefficient, and its porosity makes it possible to effectively accumulate water during rains and snowmelt. The predominance of precipitation over evaporation is characteristic for the Leningrad Region, which does not require additional moisture. The occurrence of groundwater at a depth of 5-8 $\mathrm{m}$ and the landscape without sharp elevation changes prevent the swamping of the territory. All this is favorable for the growth and development of plants.

5 Assessment of the estimated cost of reclamation work. Based on the scope of work envisaged by the reclamation project and taking into account the availability of the necessary equipment at the organization in charge, the approximate cost of the work will be 
\$ 161,218 [12]. When calculating, it was taken into account that the distance of soil transportation does not exceed $50 \mathrm{~km}$.

Disturbed land reclamation should be carried out in two sequential stages: technical and biological [13].

During the technical stage, the following works shall be performed:

- Removal of wood wastes and tires by a licensed organization for further disposal

- Backfilling and flattening of excavations with existing soil [14]. The volume of soils in the dumps is 10.8 thousand $\mathrm{m}^{3}$.

- Delivery to the object of the missing soil for filling in the amount of 7.3 thousand $\mathrm{m}^{3}$

- Flattening of the sides of disturbed sections at an angle of no more than $50^{\circ}[15,16]$

- Planning works to form a single landscape of the territory

- Compaction of the soil by bulldozering

- Delivery to the object of fertile topsoil with a thickness of $0.3 \mathrm{~m}$. The volume of the fertile topsoil will amount to 9.3 thousand $\mathrm{m}^{3}$.

The duration of the technical stage will be no more than 2 months of work in the warm season with an 8-hour work shift.

During the biological stage of land reclamation, the following works shall be performed:

- Plowing and harrowing to maintain the water-air regime of plant nutrition and destroying the soil crust

- Mechanized spreading of organic and mineral fertilizers for plant nutrition

- Sowing seeds of perennial grasses with abundant watering of the seed planting sites.

To create favorable water-air conditions for nutrition and increase the biological activity of the topsoil, it is planned to strengthen the soil and plant a specialized mixture of herbs typical for the Leningrad Region, taking into account the revealed acidity of soils [17]. The recommended composition of the mixture of herbs is: meadow bluegrass, red fescue, meadow fescue, meadow timothy, wheatgrass, and oats. All these crops are widespread in the Leningrad Region, which confirms their survival rate in these weather and climatic conditions. Seeding rate in the first year is $35 \mathrm{~kg}$ per 1 ha.

To increase the biological activity of the soil and restore its fertility, it is also envisaged to apply organic and mineral fertilizers at the rate (per hectare):

- $300 \mathrm{~kg}$ ammonium nitrate

- $100 \mathrm{~kg}$ granular superphosphate

- $400 \mathrm{~kg}$ potassium salt

The biological stage shall be accomplished only after the technical stage has been completed. Recommended agrotechnical terms for the biological stage of work are from May to mid-June: harrowing in March-April, fertilization in May, and sowing seeds in June.

\section{Conclusion}

The results of the work to justify the line of action for reclamation of land plots disturbed by opencast mining are:

- Obtaining information to characterize the territory

- Inventory of the disturbed land plots

- Determining the degree of the land degradation

- Determination of the soil fertility and the possibility of its use

- Assessment of soil contamination to determine the possibility of its use in reclamation

- Identification of centers of waste accumulation on the territory

- Determination of the geological features of the underlying soils

- Collection and preparation of data for the development of a reclamation project. 
Taking into account the chosen line of reclamation (agricultural), the reclamation should include [6]:

- The formation of land plots convenient for use in terms of relief, size, and shape, the surface layer of which should be composed of rocks suitable for biological reclamation

- Land leveling, ensuring the use of modern agricultural machinery and excluding the development of erosion processes

- Application of fertile topsoil and its use with special agrotechnical measures

- Planting of perennial crops to enrich the topsoil with organic substances using also special agrochemical, agrotechnical, engineering measures.

One of the strategic objectives of rational environmental management is to restore the productivity of disturbed lands through their reclamation. Before starting reclamation work, it is necessary to determine the most effective lines of action for further use of disturbed lands, which was the purpose of this study. The chosen line should ensure sustainable functioning of the lands and return of investment.

With land reclamation, it is possible to obtain not only economic benefits but also social ones. The social effect is achieved by improving the environmental situation in the reclaimed area, which also helps reduce the incidence of the population, improve the quality of agricultural products, drinking water, and the air. The economic effect is manifested in the possibility of obtaining income from the use of the restored lands and an increase in their cadastral value.

Thus, the environmental and economic efficiency of the implementation of a reclamation project depends on the type of disturbance, the state of the area, and the chosen line of use of the disturbed land plots.

\section{References}

1. D.A. Danilovich, A.N. Epov, M.A. Kanunnikova Data analysis of the treatment facilities of Russian cities is the basis for technological standardization, Best Available Technologies, 3, 18-28 (2015).

2. H.T. Ngoc, M. Reinhard, G. K. Yew-Hoong Occurrence and fate of emerging contaminants in municipal wastewater treatment plants from different geographical regions-a review, Water Research, 133, 182-207 (2018).

3. M.A. Pashkevich, A.V. Alekseenko, E.V. Vlasova Biogeochemical and geobotanical assessment of marine ecosystems conditions (Novorossiysk city), Water and Ecology, 3, 67-80 (2015).

4. Y.D. Smirnov, A.V. Ivanov Investigation of dust transfer processes during loading and unloading operations using software simulation, Journal of Ecological Engineering, 19 (4), 29-33 (2018).

5. A.E. Isakov, V.A. Matveeva OAO "Kovdorsky MCC" manganese-containing wastewater purification study, Obogashchenie Rud, (2), 44-48 (2016).

6. V.A. Matveeva, T.A. Petrova, M.A. Chukaeva Molybdenum removal from drainage waters of tailing dumps of Apatit JSC, Obogashchenie Rud, (2), 42-47 (2018).

7. N. Tran, M. Reinhard, K. Gin Occurrence and fate of emerging contaminants in municipal wastewater treatment plants from different geographical regions-a review, Water Research, 133, 182-207 (2018).

8. K. Rathnayaka, H. Malano, M. Arora Assessment of Sustainability of Urban Water Supply and Demand Management Options: A Comprehensive Approach, Water, 8(12), 595 (2016). 
9. B.M. Cieślik, J. Namieśnik, P. Konieczka Review of sewage sludge management: standards, regulations and analytical methods, Journal of Cleaner Production, 90, 1-15 (2015).

10. Y.L. Zhukovsky, E.V. Sizyakova Implementation of the system of energy-saving and energy efficiency at the enterprises of the metallurgical complex, Journal of Mining Institute, 202, 155 -160 (2013).

11. J. Henriques, J. Catarino, Sustainable value - An energy efficiency indicator in wastewater treatment plants, Journal of Cleaner Production, 142 (1), 323-330 (2017).

12. A.S. Tryakina Development of sustainable water treatment technology using scientifically based calculated indexes of source water quality indicators, Journal of Mining Institute, 227, 608-612 (2017).

13. C. O. Akinbile, B. T. Ikuomola, O. D. Ralphael Development and performance evaluation of low-cost wastewater treatment plant, Sustainable Water Resources Management, 5, 1217-1226 (2019).

14. Y. A.Ermolin, M. I. Alexeev Reliability measure of a sewer network, Water and Ecology, 2(74), 51-58 (2018).

15. L.A. Goldobina, P.S. Orlov Analysis of the causes of corrosion damage to underground pipelines and new solutions to improve the corrosion resistance of steel, Journal of Mining Institute, 219, 459-464, (2016).

16. A.G. Capodaglio Integrated, Decentralized Wastewater Management for Resource Recovery in Rural and Peri-Urban Areas, Resources, 6(2), 22 (2017).

17. Sh. Buzuku, A. Kraslawski Application of morphological analysis to policy formulation for wastewater treatment, Journal of Mining Institute, 214, 102-108 (2015).

18. A.C. Mecha, M.S. Onyango, A. Ochieng, M.N.B. Momba Ultraviolet and solar photocatalyticozonation of municipal wastewater: Catalyst reuse, energy requirements, and toxicity assessment, Chemosphere, 186, 669-676 (2017).

19. F. Zhang, X. Huang, Y. Shi, J. Zhong, Z. Ding Study on deep dewatering and resource utilization of sludge in municipal sewage treatment plant, AIP Conference Proceedings, 2106, 20-24 (2019).

20. Z. Zhang, B. Li, N. Li, M. Sardar, T. Song, C. Zhu, X. Lv, H. Li Effects of UV disinfection on phenotypes and genotypes of antibiotic-resistant bacteria in secondary effluent from a municipal wastewater treatment plant, Water Research, 157, 546-554 (2019).

21. I.A. Antonova, O.N. Gryaznov, O.M. Guman, A.B. Makarov, O.V. Kolosnitsina Geological conditions for allocation of solid municipal and industrial waste disposal sites in the Middle Urals, Water Resources, 41(7), 896-903 (2014).

22. A.S. Danilov, Y.D. Smirnov, D.S. Korelskiy Effective methods for reclamation of area sources of dust emission, Journal of Ecological Engineering, 18 (5), 1-7 (2017).

23. A.V. Ivanov, Y.D. Smirnov The impact of anthropogenic alluvial arrays on areas settlements depending on the particle size distribution of stored tailings, Journal of Ecological Engineering, 17 (2), 59-63 (2016).

24. A.V. Ivanov, Y.D. Smirnov, G.I. Petrov Investigation of waste properties of subway construction as a potential component of the soil layer, Journal of Ecological Engineering, 19 (5), 59-69 (2018). 